\title{
KÖZELKÉP
}

\section{Etnikai kategóriák és a migráció összefüggései Beregszászon}

\author{
HIRES-LÁSZLÓ KORNÉLIA ${ }^{1}$
}

\begin{abstract}
ABSZTRAKT
A tanulmányban megpróbáljuk bemutatni, hogy Beregszászon végzett, a hétköznapi etnicitás vizsgálatára szervezett fókuszcsoportos beszélgetésekben, milyen migrációs tendenciák rajzolódnak ki, és ezekben a migrációs folyamatokban miként jelenik meg az etnicitás. A tanulmányban elsősorban a kutatás során tapasztaltakat foglaljuk össze, melyet 2016 nyarán végeztünk és reflektálunk egyes leírásban azokra a változásokra, melyek azóta történtek 2017 nyaráig. A tanulmány elsősorban leíró jellegü és csak az etnicitás, etnikai kategóriák tárgykörén belül értelmez dolgokat, nem célunk összehasonlítani a következtetéseket korábbi migrációs kutatások eredményeivel. Az elemzésben a szociálkonstruktivizmus módszertani megközelítést alkalmazzuk, és célunk a diskurzusok segítségével bemutatni: miként konstruálódnak a vélemények, illetve az eltérō vélemények miként alkothatnak egységet.
\end{abstract}

KULCSSZAVAK: migráció, etnicitás, Kárpátalja, fókuszcsoport, diskurzuselemzés, szociálkonstruktivizmus

\section{ABSTRACT}

\section{Ethnic categories and the context of migration in Beregszász}

In the paper, we try to demonstrate what migration trends in Beregszász have been conducted in focus group discussions on everyday ethnicity, and how ethnicity appears in these migration processes. In the study, we mainly summarize the findings of the research, which we carried out in the summer of 2016 and reflected in some descriptions of the changes that have taken place since the summer of 2017. The study is primarily descriptive and only interprets issues within ethnicity and ethnic categories, we do not aim to compare the conclusions with previous migration research results. In the analysis, the social constructivism methodological approach is applied. Our aim is to present the discourses: how the opinions are constructed and differing opinions can form unity.

KEYWORDS: migration, ethnicity, Transcarpathia, focus group, discourse analytical approach, social constructivism

${ }^{1}$ Főiskolai adjunktus, kutató, II. Rákóczi Ferenc Kárpátaljai Magyar Főiskola, Hodinka Antal Nyelvészeti Kutatóközpont. 


\section{KÖZELKÉP}

\section{Bevezető}

A 2013 decemberétől 2015 nyaráig történt események Ukrajnában markánsan átalakították az ország politikai és gazdasági helyzetét. Az országban eleinte békés tüntetésként indult az a folyamat, amelynek eredménye volt a teljes hatalomváltás, és ezt a főváros, Kijev utcáin vívott harcok kísérték. A Krím-félsziget elcsatolását követően a keleti országrészben elkezdődtek a zavargások, és az ukrán nacionalista új rezsimmel szemben az oroszbarát szimpatizánsok fegyvert ragadtak. Az egyszerü zavargásból végül hidegháborús helyzet alakult ki (bővebben az Ukrajnában történtekről lásd Fedinec - Halász - Tóth 2016, Csernicskó 2016). A háború kitörését követően az emberek hétköznapjaiba már nemcsak a politikai és gazdasági instabilitás szivárgott át, hanem az is mind gyakoribbá vált, hogy a sorkatonaság, katonai behívók elől a férfiak, legtöbbször családapák, menekültek külföldre, majd a család többi tagja is követte őket családegyesítés céljából. Ennek a változásnak köszönhetően a Kárpátalján élő magyarok élete is átalakult, és az alakulás jelenleg is folyamatában van. A Beregszászon készített vizsgálat (2016) az etnicitás tárgykörén keresztül egy új társadalmi változás bemutatását is szolgálja - az etnicitás és a társadalmi folyamatok vizsgálatában a migráció, mint a kárpátaljai magyarság jövőjének és megmaradásának egyik legfontosabb kérdésévé kezdi kinőni önmagát.

Több elemzés is napvilágot látott már a kárpátaljai magyar identitással kapcsolatosan (Orosz - Molnár 2007; Csernicskó - Soós 2002; Gereben 1999; 2005; Hires-László 2010), ezek többé-kevésbé olyan jellegű vizsgálatok voltak, amelyek az identitás képlékenységét, a konstruktivista szemléletet figyelmen kívül hagyták. Az eddigi vizsgálatok azt a strukuralista szempontot követték, amely az identitás kemény tulajdonságait hangoztatva statikus mivoltát értelmezik nemzeti keretek között, míg az újonnan elterjedt etnicitás vizsgálatokban azokra a „puha” identitást alakító tényezőkre keresik a választ, amelyek az etnikai csoporthoz tartozás során relevánssá válnak egy személy identitásának alakításában (Brubaker - Cooper 2000). Vagyis az utóbbi szemlélet nem zárja ki annak alakulását, esetlegesen a teljes megváltozását sem. A konstruktív identitás jellemzői - konstruáltság, esetlegesség, labilitás, sokféleség, képlékenység - olyannyira gyökeresen megváltoztatták az identitás vizsgálatát, hogy a korábbitól teljesen eltérő megvilágításban, fogalmakkal írják le az etnikai csoportokhoz tartozást (Brubaker - Cooper 2000; Stachel 2007). A szociálkonstruktivizmus megközelítésében - szemben a konstruktivizmussal - lehatárolja a jelentések tartalmát, azt hogy az elképzelések, valamint attitűdök miként és hogyan fejlődnek a társadalmi kommunikációban (Galbin 2014).

\section{Elméleti keret: szociálkonstruktivizmus és az etnicitás}

A szociálkonstruktivizmus egy episztomológiai (módszertani) megközelítés, ahol arra világítanak rá, hogy a különböző vélemények miként alkothatnak egységet, mi- 


\section{KÖZELKÉP}

ként konstruálódnak (Berger - Luckman 1991), és nem pedig ontológiai, mint a relativizmus, amelyben két végletként jelenik meg az objektív valóság és a megvalósult valóságok (Hammersley-Atkinson 2007). Az egyén és a csoport interakciója a társadalmi rendszertől függ, fogalmak vagy gondolatok az interakcióban résztvevőktől. A szokatlan jelenségek ismétlése és az azok szerzőinek másolása eredményeként jön létre a korábban szokatlan jelenség intézményesülése (Cojocaru 2010 in Galbin 2014:84). A valóság társadalmilag megalkotott; a valóság megalkotása nyelvhasználaton keresztül történik, éppen ezért használják a diskurzuselemzést a társadalmi jelenségek alakulásának elemzéséhez, így a beregszászi lakosokkal végzett beszélgetést is a diskurzus elemzés (Jorgensen-Phillips 2002) módszerével a szociálkonstruktivizmus szemléletével végezzük.

A témául választott hétköznapi etnicitás vizsgálatában szociálkonstruktivizmus mentén az válik lényegessé, hogy milyen társadalmi, gazdasági és politikai körülmények között, illetve milyen hatások közepette történik meg az etnikai különbségek és közösségek reprodukciója. Feischmidt (2010) megfogalmazásában összefoglalja - egy a témában megjelent összefoglaló kötet bevezetőjében - mindazokat az eredményeket, melyek az említett nézőpontváltás következtében az etnicitás kapcsán megjelentek: „Az etnicitás szerintünk mindenekelőtt egy viszonyt és hozzá kapcsolódóan egy strukturálisan is fontos látásmódot jelöl, amely az elhatárolódás és a különbségtétel társadalmi praxisaiban realizálódik. A társadalmi viszonyokba ágyazva a különbségeknek egy meghatározott rendjét hozza létre: ami az etnikai kategóriával jelölteket elkülöníti a homogénnek tekintett jelöletlenektől, és a relációhoz többnyire egy hatalmi viszonyt társít" (Feischmidt 2010: 7-8). Értelmezését úgy folytatja, hogy az etnicitás nem más, mint küzdelem, amit a közösség nevében folytatnak különböző erőforrásokért, melyhez párosul az identitáspolitika, amely az „intézmények és beszédmódok teremtésével erősíti az alteritás hangjait" (Feischmidt 2010: 8). Összességében tehát úgy tekintünk a továbbiakban az etnicitásra, mint különböző etnikai kategóriák alapján egyénenként eltérő módon megalkotott élethelyzetek, jelenségek, vélemények. A kategóriák kulturális tölteteinek eltérő relevanciájára fektetjük a hangsúlyt, illetve a társas identitás kapcsán nem hagyjuk figyelmen kívül a kategóriák közötti átjárhatóság lehetőségét sem.

\section{Hétköznapi etnicitás kutatása Beregszászon}

A kárpátaljai magyarság hétköznapi etnicitás vizsgálatához készült tehát az a beregszászi lakosokkal végzett fókuszcsoportos beszélgetés (a módszerről bővebben Vicsek 2006), amelynek egy szegmense az elvándorlással foglalkozott. A beszélgetés témakörei főként a mindennapokban átélt és megtapasztalt etnicitással kapcsolatba hozható témakörökre épített. Fő kutatási kérdésünk az volt, hogy: Mikor, milyen élethelyzetekben, szituációkban, körülményekben, intézményekben, fizikai és mentális 


\section{KÖZELKÉP}

terekben élik át és tagolják etnikai ismérvek mentén a mindennapi életüket, és fóként társadalmi tevékenységeiket Beregszász lakosai? Mely életterek, események azok, amelyek etnikailag semlegesek? A beszélgetések során több mindennapos probléma mellett lett megkérdezve a migráció is. Az elvándorlással kapcsolatban elhangzott vélemények feldolgozására vállalkozunk jelen tanulmányban. A beszélgetés többi témakörei közé tartozott a városban tapasztalható problémák, az államnyelvtudás, iskoláztatás (tannyelv-választás), állampolgárság, etnikai kategóriákba sorolás, nacionalizmus a mindennapokban, a politikai élet követése, baráti kapcsolatok, érdekérvényesítés lehetőségei stb. A beszélgetések kezdeményezéseként több olyan témakört is említettünk, ahol csak a város mindennapjait, a mindennap megélt problémákat vitathatták meg a résztvevők. A vizsgálatot az Erdélyben (Kolozsváron) végzett, fent már említett hasonló jellegú kutatás inspirálta (Brubaker és mts. 2011). A továbbiakban részletesen bemutatjuk a beregszászi kutatás legfontosabb paramétereit, melyek a kutatás eredményeinek értelmezéseinél válhatnak lényegesekké.

Összesen hat beszélgetést sikerült megszervezni, lebonyolítani illetve elkészíteni a hanganyagok átiratát. A hanganyagok a két és három órás időintervallumban mozognak. A csoportok létszáma három és hat között mozgott, összesen 29 adatközlő vett részt. A kutatás tervezésénél több szempontot is állítottunk a beszélgetéshez felkért adatközlők kiválasztásához, melyből néhányat kénytelek voltunk rugalmasabban kezelni. A kivitelezés idejében csak azokat a személyeket tudtuk megszólítani egyéni kapcsolatokon keresztül, akik bizalommal voltak a kutatás szervezőjével, és ennek a bizalomnak köszönhetően merték elmondani a véleményüket. Ugyanis a szervezés és lebonyolítás idején már nem zajlottak harcok az országban, de a félelem nagyon sokakban ott volt. A szervezésnél elvként szerepelt, hogy aktív korosztályú, beregszászi lakosok legyenek az interjúalanyok, ennek ellenére egy csoportos beszélgetés során egy kollektívával, egy összeszokott csapattal beszélgettünk, ahol részt vettek a környező települések lakosai is. Valamint a résztvevők között három nyugdíjas volt jelen, akik kiemelték véleményüket, hangoztatva, hogy nyugdíjasként ők másként látják a körülöttük zajló dolgokat, eseményeket, a fiatalabb korosztálylyal szemben. Azokat a véleményeket, melyek a környék településeiről származóktól hangzottak el, csak a kárpátaljai magyarságra vonatkozó témáknál használtuk fel, illetve a városban tapasztalható jelenségek értékelésénél mint külső véleményezőket iktatjuk be elemzésbe. A kiválasztással szemben támasztott szempontok módosítása mindkét esetben (a nyugdíjas korosztály beemelése és egy-két környék falvaiban lakók megkérdezése) a kutatás következtetéseinek levonásában csak pozitív töltetet adott. Az előre támasztott kritériumokkal a település csak egy bizonyos rétegének véleményét ismerhettük volna meg, míg így - a módosításnak, bővítésnek köszönhetően - újabb meglátások is bekerülnek az elemzésünkbe, és ezzel a lépéssel közelebb kerülhetünk a szociálkonstruktivizmus által előírt eltérő vélemények feltérképezéséhez. A kutatásban résztvevő 29 adatközlőből 16 beregszászi születésű és 3 olyan 


\section{KÖZELKÉP}

adatközlő volt, aki nem beregszászi lakos. Azok az adatközlők, akik bekerültek a városba, tizenöt éve legalább már a településen élnek és azt megelőzően is a legtöbben a Beregszászi járásában éltek. A legmesszebbről egy técsői származású hölgy volt, aki mellesleg ötvenhárom éve él a városban.

A kutatás megszervezését előzte meg az a próbabeszélgetés, melyet a beregszászi főiskolán dolgozó városlakókkal készített a kutatás vezetője. Ezen a beszélgetésen próbálta ki a csoportos beszélgetés lebonyolításának metódusát, illetve tesztelte a hétköznapi etnicitás vizsgálatához elkészített vezérfonalat. Az elemzésekben olykor erre a beszélgetésre is hivatkozunk. A próbabeszélgetés tapasztalatai alapján a kutatás vezetője módosított a beszélgetés menetén, ahol első ízben kerülte az etnicitással kapcsolatos témákat, és toborzásnál a várossal kapcsolatos dolgokra fektette a hangsúlyt. A próbabeszélgetés során kevésbé tértek ki az etnikai tényezőkre a résztvevők, így a többi beszélgetés szervezésénél a toborzás során már konkretizálta a beszélgetés tárgyát, megjelölve az etnicitást. Kihangsúlyozta, hogy jó volna, ha a beszélgetés során megvitatnák az ukránok és magyarok együttélését a településen. Ezzel a tudatosan előirányzott etnicitással kezdődött tehát a beszélgetés, mivel az etnikailag semleges beszélgetésekből több száz órás hanganyagot kellett volna készíteni az etnikailag semleges témák valódi etnizálásának feltérképezéséhez. Ezzel az „erőltetett” etnicitással tudatosan irányoztuk elő a résztvevőknek, hogy ahol tudják, ott hívják elő tapasztalataikban azokat az eseteket, véleményeikben azokat a gondolatokat, ahol a megélt eseményeket valamely etnikumhoz tudják kapcsolni. A csoportos beszélgetés kezdete előtt minden adatközlő kitöltött egy kérdőívet, melyben megkérdeztünk néhány lényeges információt (mikor és hol született, mikor került a városba, nemzetisége, a végzett iskolák tannyelve, ingázása országon belül, azon kívül). Egy előzetes elemzésben már kitértünk arra, hogy a nemzetiség megjelölése ezen a kérdőíven végül beépült az egyik beszélgetésbe is, és a megvitatásban lényeges meglátásokat észlelhettünk a nemzeti identitás meghatározásánál (Hires-László 2017).

\section{Az etnicitás és a migráció kapcsolódási pontjai Beregszászon}

Az etnicitás és a migráció kapcsolatáról több szakirodalom is szól, melyekből számunkra azok válnak jelenleg lényegesekké, melyek a magyar etnikumhoz kapcsolódnak. A migráció kapcsán fontos megjegyeznünk, hogy napjainkban a rendelkezésre álló mobilitási lehetőségek hatalmas változásokat idéztek elő az ideiglenes és állandó helyváltoztatás vizsgálatában, valamint a Szíriából érkező migránsáradat a migráció kutatás legnagyobb hányadát teszi ki. A magyar etnikumokat érintő migrációs tendenciának szakirodalmát osztotta fel Feishmidt Margit és Zakariás Ildikó (2010) a helyváltoztatást kiváltó okok mentén: Az első csoportba sorolják azokat az 


\section{KÖZELKÉP}

etnikai migrációban kialakult megközelítéseket, melyekben a migráció a célország kulturális vonzása következtében jön létre (return migration). Ez alatt a határon túli magyarság körében jellemző anyaország vonzását értik. A szerzőpáros időrendben áttekintik, miként viszonyult az állam a diaszpórából hazatérő nemzettársakhoz, vagyis bemutatják az anyaország nemzeti identitáspolitikáját. A másodikként említik a gazdasági motivációkat, ahol elsősorban a munkaerő-piacon jelentkező kereslet és kínálat között kiegyenlítődés történik. Itt az anyaország mint szimbolikus és társadalmi tőke jelenik meg. Legvégül a kibocsátó ország rossz kisebbség-politikája miatt máshol próbálnak az elvándorlók boldogulni. Az utóbbi esetben tehát a kisebbségi sorsból, a többségi diszkriminációból menekülés a kiváltó ok.

A kolozsvári hasonló jellegű kutatás elemzésénél a migráció fejezetben (Brubaker és mts. 2011) a szerzők azzal indítják a beszélgetések elemzését, hogy a legtöbb esetben fel sem kellett vetni az elvándorlás kérdését, hanem a megélhetéshez és a jövő tervezéséhez automatikusan társították a vándorlást. Ugyanígy a beregszászi beszélgetések során is asszociáltak az elvándorlásra a megélhetési lehetőségek boncolgatásánál, illetve más aktuálisan migrációval párhuzamba hozható jelenségek is felmerültek. Ezek elsősorban a kettős állampolgárságról és az országban jellemző háborús helyzetről szóltak. A továbbiakban szeretnénk áttekinteni magát a migrációs tendenciákat és az elvándorlás kérdéskörét a beszélgetések alapján, valamint a migráció témában etnicizált diskurzusokat és meglátásokat.

Ahogy a kutatás paramétereinek bemutatásából kiderült, a beregszászi kutatás toborzásánál konkretizáltuk a beszélgetés tematikáját és a tervezett disszertáció megírásának lehetőségét. Egyik adatközlő még a beszélgetés legelején hangot adott véleményének - és ezzel alakítva a beszélgetés menetét - ugyanis a megélhetési gondokra hívta fel a figyelmet, mely szoros összefüggést mutat a migrációval. A beszélgetés további részében is fóként a megélhetés nehézségeit tárgyalták az adott beszélgetés során, de a többi beszélgetésben is spontán került elő az elvándorlás kérdése.

Mariann (vállalkozó, 40 éves): „Ez szerintem nagy probléma, a legnagyobb probléma manapság. Itt ezt, ezt mindenki megérzi, aki valamivel foglalkozik, és hogy mennyire az emberek mennek el, mert nem tudnak megélni az itteni fizetésből. (...) Nem is a magyarok meg az ukránok közötti valami feszültség vagy, vagy más, nem. Szerintem nem ez a fó téma, hanem az, hogy mennek el innen az emberek. Ez, ez szerintem egy, egy+/. [nevet] Erről lehetne egy akkora disszertációt írni, hogy csak na!" (Fcs1)

Az adatközlő, aki szerint sokkal lényegesebb a megélhetési gondok vizsgálatát megragadni és felszínre hozni, vegyes házasságban él, gyermekeit eleinte ukrán iskolába járatta, majd a felsőbb osztályokban átirányította őket magyar tannyelvűbe. A családjában teljesen természetes a vegyes etnikumok harmonikus egymásmellettisége, és nem tartja lényegesnek az emberek etnikumokhoz tartozását. Számára sok- 


\section{KÖZELKÉP}

kal fontosabb, hogy a vállalkozásában dolgozó munkásainak nem elég a megélhetéshez az általa kínált bérezés és éppen ezért többen inkább külföldi munkavállalást választják. Az elvándorlásnak tehát legtöbbször az anyagi jobblét a motiváló ereje, amellyel szinte ellentétként kerül előtérbe a helyben maradás, az erős lokális érzet. A következő interjúrészletekből ez az ellentét jól kiéleződik, ugyanis az egyik résztvevő az anyagi jólétet szembe helyezi a lokális identitással (Appadurai 1996). A diskurzusban a hangsúly tehát arra helyeződik, hogy a lokális lehetőségek kiaknázására kellene törekedni - ezt a véleményt a lokális identitást hangoztató és szorgalmazó résztvevő fejti ki részletesen. A véleményformálást követően többen igazodtak az elhangzottakhoz és ellenvélemény - amely cáfolta volna a kijelentést - igazából nem érkezett.

Anna (pályázati referens, 23 éves): „Mert azt gondoljuk, hogy hozzánk fog igazodni például Beregszász, meg hozzánk fog igazodni a város, meg a fizetés, és közbe, lehet, hogy fordítva kellene. Tisztázni kellene, hogy mik a lehetőségek, és nekünk igazodni ahhoz, hogy mit lehet ebből a városból kihozni [...] Mert, hogy ha mindenki úgy áll hozzá, hogy magasak az elvárásai, közben meg nem lehet annyi mindent kihozni+... [mosolyog] Vagy legalábbis azt hiszi, hogy a város érte él, közbe pedig mi vagyunk a városért. Legalábbis én így képzelem el, hogy//+."

Mariann: „Nahát, ez egy másik szempont, ezt meg lehet érteni. Csak ugye csábító az, hogy külföldön a sokszorosát lehet megkeresni. Nem is az a baj, be lehetne osztani szerintem az itteni keresetet is, csak ugye ott a nagy csábítás."

A kettős állampolgárság teljesen átrajzolta a kárpátaljai emberek megélhetési lehetőségeit, és míg korábban a külföldi munkavállalás vagy a teljes kiköltözés csak bizonyos személyek számára volt elérhető, úgy mára a kárpátaljai magyarok - és esetekben a nem magyarok - körében bárki élhet a magyar állampolgárság adta lehetőséggel. Korábban a kapcsolatrendszertől vagy bizonyos alaptőkétől függött az elvándorlás lehetősége, mára szinte mindenki számára ott van az a lehetőség, hogy igényelheti a kettős állampolgárságot, amellyel garantált a külföldi munkavállalás. Több beszélgetésben is elhangzott, hogy a magyar állampolgárság megszerzésének különböző illegális változata is él a térségben, amikor a magyarul nem beszélők is megszerezhetik maguknak a magyar dokumentumokat, ám a további felhasználásuk érdekében kénytelenek megtanulni a magyar nyelvet. A térségben újabban több olyan lehetőség lett létrehozva a nagy érdeklődés miatt, ahol elsajátítható a magyar nyelv². Az egyik adatközlő a sógornőjének az esetén keresztül érzékeltette a problémát, miszerint a magyar útlevelet hiába megszerzik a magyarul nem tudó kárpátaljaiak, ha a határátkelésnél nem tud válaszolni a hozzá intézett kérdésekre.

${ }^{2}$ Tömegesen vesznek részt a Magyar Állam támogatásával biztosított tanfolyamokon http://www. karpataljalap.net/?q=2017/07/04/magyar-mint-idegen-nyelvtanfolyamok-indultak-karpatalja-szerte-harmadik-alkalommal, de ezen kívül számtalan nyelvstúdió és egykori pedagógusok is oktatják a magyar nyelvet a szláv lakosok számára. 


\section{KÖZELKÉP}

Mariann: „Hová megy? Látogatóba? Szálljon ki! Nyissa ki a kapotot+...[motorháztető] vagy mit tudom én, a csomagtartót. Ha ennyit már tud, akkor azzal nincs gond. Aki egyáltalán nem tud, annak nagy+... Hiába megszerezte pénzért vagy akár hogyan, nem ér vele nagyjából semmit, mert most már nagyon szigorítva van (az ellenőrzés)." (FCS1)

Az Ukrajnában, Kárpátalján 2014-ben az emberek zöme nem feltétlenül csak a külföldi munkavállaláshoz, esetleg tanulmányok folytatásához, nyugdíjak megszerzéséhez, jobb egészségügyi ellátás igénybevételéhez, az olcsóbb nyugati autók megszerzéséhez használták az újonnan megszerzett magyar okmányokat, hanem hogy a férfiak meneküljenek a sorozások elől. Az ország keleti részében dúló harcokhoz eltérő módszerekkel és intenzitással próbálták a sorkatonaságra köteles fiatalokat, valamint az egykor katonai szolgálatokat teljesített férfiakat besorozni. Az ország politikai és gazdasági instabilitása teljesen átrajzolta a kettős állampolgárság birtoklásának előnyeit. A nemzeti érzelmeken túl a gazdasági és egyéb pozitív előnyökkel járó immáron kettős állampolgárság egyes férfiaknak a háború előli menekülést jelentette. A magyarországi külképviseletek gyorsított eljárásban igyekeztek elbírálni a magyar állampolgársági kérelmüket azon kárpátaljai magyar férfiak számára, akik a háború kitörésének idejéig nem igényelték és kapták meg. Ezt követően az útlevél megszerzésében is hasonló segítséget nyújtottak. Olyan személyek kényszerültek a külföldi munkavállalásra ebben az időszakban, akik korábban sosem dolgoztak külföldön, és nem is tervezték sem a saját, sem a családjuk jövőjét máshol a világban. De a sorozások elől menekülő férfiak először csak munkavállalás céljával indultak útnak, hogy ne tartózkodjanak az országban, s ne tudják kézbesíteni számukra a behívókat, ám ezt követően többen vitték magukkal az egész családjukat. Így legtöbb esetben az eleinte kényszerből indult körkörös migráció végül az egész család teljes kiköltözését eredményezte. A nyugaton tapasztalható magasabb életszínvonal sokakat csábított el. A következő diskurzusban a résztvevők kiegészítve egymás véleményét összefoglalják a migrációval (a kárpátaljaiak elvándorlásával) kapcsolatban általánosnak mondható tendenciákat ${ }^{3}$.

Viola (nyugdíjas, 76 éves): „A háború dobálta szét a fiatalokat, hogy ne menjen katonának a sok fiatal. Igen."

Éva (könyvtáros, 52 éves): „Meg a megélhetés.”

Viola: „Meg a megélhetés. „

${ }^{3}$ 2011-ben kvantitatív és kvalitatív módszereket is használtak annak a kutatásnak a lebonyolításához, amelyet a magyarországi bevándorlók körében végeztek. A kutatás összefoglaló kötetében (Göncz - Lengyel - Tóth szerk. 2012) értelmezik és elemzik az adatokat, és Kisfalusi Dorottya írásából kiderül több szociodemográfiai adat mellett azt is, hogy a magyarországi bevándorlók migrációs céljaiban és motivációiban az Ukrajnából érkezők körében elsősorban a családi okok kimagaslóan magasak; valamint azt is megtudhatjuk, hogy a jobb megélhetés érdekében szintén Ukrajnából érkeznek leginkább (Kisfalusi 2012). Az ukrajnai zavargások Kárpátalján érezhető hatását értékeli Tátrai Patrik, Erőss Ágnes és Kovály Katalin (2016), és a legnagyobb hangsúlyt a migrációs hajlandóság kiértékelésére helyezik elemzésükben. 


\section{KÖZELKÉP}

Éva: „Akkor amikor kiment a rendszerváltás után egy család+... azok a jó módúak voltak, akik úgy indultak el, hogy anyagilag megvoltak alapozva, és akkor ott tudtak valamit kezdeni az életükkel. Én akkor is mindig azt mondtam, hogy most mért menjek én át? Mert akkor is sokan kérdezték: Ti nem mentek? Nem mindegy, hogy hol vagyok én szegény - ott vagy itt?"

Viola: „Hát igen.”

Éva: „Most pedig a kényszer viszi rá az embereket, a kényszer hajtja. Szerintem most se sokan települnének át, ha nem azt látnák, hogy ott jobban megtudnak élni mint itt."

Zoltán (kőmúves, 49 éves): „Megélni lehet itt is csak akarni és tudni kell.” (FCS2)

Az etnicitás, a magyar nyelvtudás mint tőke jelenik meg a kárpátaljai és a többi határon túli magyar térségből az anyaországba vándorló magyarok körében (return migration). Erre hívja fel a figyelmet Feischmidt Margit és Zakariás Ildikó (2010:153), hogy „noha a migráció strukturálisan - elsősorban a gazdaság és a munkaerőpiac törvényszerüségeinek engedelmeskedve - transznacionális térben zajlik illetve transznacionális teret hoz létre, a migránsok gyakran az etnicitás és a kulturális nemzet kategóriáiban értelmezik tapasztalataikat". Ugyanebben a formában jelenik meg a nyelvtudás is és az etnikai kategóriákban gondolkodás is a következő idézetben. A magyar nyelvtudáson keresztül és a magyar kapcsolatrendszeren belül gondolják végig a migráció folyamatát, és a Magyarországon túli migráció folyamatát is a magyar etnikumhoz kapcsolják.

Mariann: „A mieink mennek Németbe is Angliába is, de a nyelvtudás hiánya inkább Magyarországon állítja meg őket, mert magyarul mindenki tud."

Anna: „De már Angliába is rengeteg magyar van szerintem.”

Mariann: „Ühüm.”

Anna: „Nagyon-nagyon sok magyar van. Tehát ott is meglehet találni azt a magyar közösséget, ahol lehet dolgozni."

Az állampolgárságot igénylők körében két végletet láthatunk, egyrészről a racionális megfontolás, másrészről az emocionális, melyek alkalmanként keveredhetnek is. A háború kitörését megelőző időszakban is többen az állampolgárság megszerzésének a gazdasági hozadékait tartották szem előtt Kárpátalján. A kárpátaljai magyarok körében a másik oldalon voltak azok, akiket épp a gazdasági előnyök tántorítottak el az állampolgárság megszerzésétől. Az interjúalanyok között voltak olyan résztvevők, akiknek az újonnan megszerezhető állampolgársággal járó előnyök morálisan összeférhetetlennek tűntek azzal, hogy az áhított magyar állampolgárságot gazdasági célokra is felhasználják. Ezekben az esetekben az állampolgárság megszerzése azt jelentette, hogy végre magáénak tudhatta a nemzetiségével megegyező állampolgárságot, és ez egy morális, érzelmi többletet is jelentett az illetőnek. Másik végletként jelennek meg azok a személyek, akik korábban nem mutattak kapcso- 


\section{KÖZELKÉP}

latot a magyar etnikai kategóriával, ám gazdasági előnyök kihasználása érdekében megtettek mindent, hogy kettős állampolgárok legyenek. Az ilyen esetekben az elfelejtett magyar nyelv újratanulása is előfordulhatott. A morális értékrendet követők köréből olyan interjúalanyok is részt vettek a beszélgetésen, akik számára „csak” egy okmánynak tűnt a honosítási okirat megszerzése, és nem feltétlenül szántak rá időt és energiát annak megszerzésére (esetleg pénzösszeget a dokumentumok fordíttatására). Valamint gátló tényező volt sokáig a kárpátaljai magyarok számára az is, hogy Ukrajna miként kezeli majd a kettős állampolgárságot - ez a kérdés lényegében még mai napig is tisztázatlan ${ }^{4}$. A kelet ukrajnai harcok kezdete után ezek a tényezők markánsan megváltoztak és a félelmet, illetve a gazdasági előnyöktől elzárkózást a jövő biztosítása váltotta fel. A magyar állampolgárság az esetlegesen szükséges menekülési okmányokat jelentette kárpátaljai magyar férfiak és családok számára. A következő idézetből jól érezhető, hogy az aktuális események 2016-ban már menynyire átrajzolta a megszerzés igényét.

Zsófia: „Nem, csak azt akartam, sok ukránnak hamarabb van kettős állampolgársága."

Lilla: „Bátrabbak voltak.”

Zsófia: „Hamarabb gondolkoztak rajta, mint mi magyarok, mert amikor Magyarországon voltam tavalyelőtt, tavaly+/."

Anikó: „Tavaly.”

Zsófia: „Tavaly februárba, akkor jöttem rá, amikor kijelentették, hogy tizenháromezer itteni külhoni magyar vette fel az állampolgárságot, oszt még a magyarok köztük sincsenek, akik tényleg magyarok itt nálunk, és még most adják be mint hallom nagyon sok olyan magyar, aki tényleg magyar a leszármazottja, a nagyapja, dédnagyapja, és még mindig gondolkozik, hogy beadja, vagy még most akarja, vagy most adta be, csak ezzel ennyit akartam.”

Anikó: „És nem kapja megfele.”

Zsófia: „Vagy még nem kapja megfele, ez meg a másik, igen.”

Az elvándorlás kényszerhelyzetét nemcsak a katonaköteles férfiak és azok családjai élték/élik meg, hanem azok a magyarországi nyugdíjban részesülők is, akik igényelték a sokkal jobb összeggel járó magyarországi nyugdíjat, de lényegében életvitelszerűen Kárpátalján tartózkodtak. Erre azért kényszerülnek a kárpátaljai nyugdíjasok, mivel az ukrán állam által folyósított nyugdíj összegének legtöbbször akár a hat-nyolcszeresét is megkapják. Az ukrajnai nyugdíjakból csak azok tudnak megélni, akik mellette dolgoznak, esetleg háztáji gazdálkodással foglalkoznak, vagy a többgenerációs együttélésnek köszönhetően a fiatalok segítik az idősek megélhetését. A magyarországi nyugdíjfolyósításhoz szükséges, hogy az illető életvitelszerűen az adott országon belül tartózkodjon. Ennek ellenőrzésére korábban kisebb

\footnotetext{
${ }^{4}$ http://www.karpataljalap.net/?q=2017/07/05/szelsoseges-felvonulok-es-kettos-allampolgarsag
} 


\section{KÖZELKÉP}

hangsúlyt fektetett a magyar bürokrácia, de az egyre több nyugdíjast érintő kettős életvitel miatt minden lehetséges módon ellenőrzik az adott helyen tartózkodás tényét. Vagyis az a személy, aki állandó lakcímmel és magyarországi nyugdíjjal rendelkezik, az a szigorítások miatt kénytelen valóban életvitelszerűen a bejelentett címen tartózkodni. Az ellenőrzés különböző módon történik: részben a helyi polgármesteri hivatal dolgozói, vagy a helyi postás tanúsítja, hogy valóban gyakran jelen van-e az illető személy a településen, illetve mindezek mellet olykor a bejelentett lakcím szomszédjait is megkérdezik. Leginkább az ukrán-magyar határmenti övezetben jellemző ez az erős szigorítás, de Magyarország többi régiójára is kiterjesztették az ellenőrzést, viszont nem olyan intenzitással, mint a szabolcsi régióban. A szigorítás miatt több nyugdíjas kénytelen első ízben ideiglenesen több időt tölteni Magyarországon, majd ezt a hosszabb kint tartózkodást, körkörös migrációt gyakran követi a végleges költözés. Ezt a változást a beszélgetők több ízben is felemlegették, és azt is megjegyezték, hogy az ilyen jellegü kényszeres helyváltoztatást több kárpátaljai magyar idős nehezen éli meg. Egy fent vázolt rendszer szigorítását is kijátszó esetet olvashatunk a következő idézetben, amelyben a kárpátaljai magyarságra jellemző leleményesség ismét bebizonyosodik: egy nénike az ukrán-magyar határon történő cserekereskedelmet hasznosította a nyugdíja megszerzéséhez.

Anna: „Ez viszont, ez viszont egy nehéz dolog, mert nekünk is a rokonaink most próbálták megkapni Magyarországon a nyugdíjat, és nem nagy sikerrel, mert, hogy úgye ott kell tartózkodni, ahová be van az ember jelentve, ott kell tartózkodni. Hallottam egy olyan történetet is, hogy a nem tudom hány éves nénike, azt csinálta, ide volt bejelentve Surányba, valamelyik faluba, nem Surányba volt bejelentve, és minden egyes nap átment, de csak átment. Vitt egy kis ezt-azt, leült az egyik lócára, és beszélgetett a falubéliekkel. Senki nem tudta, hol lakik, de ő ott ült, beszélgetett mindenkivel, megvolt már a kapcsolati hálója, és amikor jöttek a nyugdíjat hozni, akkor kérdezték is: Hát Ilonka néni? Ja, Ilonka néni. Hogyne tudnánk ki az, jaj, adja ide, majd mi odaadjuk. És mindenki tudta, hogy Ilonka néni, majdnem, hogy nem surányi. Tehát, hogy ezt így is meglehet oldani. Minden nap szépen átbiciklizett a határon Asztélyból. És ott ült minden nap, nem kellett neki+... De van, aki muszáj, hogy átköltözzön. És az a baj, hogy most már nemcsak a fiatalság, hanem most már a nyugdíjas korosztály is inkább átköltözik, hogy akkor ott kapja a nyugdíját. Mert, hogy eddig úgy volt ugye, megkapták, megkapták. Juj, de jó! De most már ellenőrzik, is tehát+..."

A kárpátaljai magyar idősek körében tehát egyre inkább elterjedt a magyarországi nyugdíj megszerzése. Ez a lehetőség nem mindenki számára elérhető, ugyanis magas összeggel jár az ügyintézés. A kettős állampolgárság megszerzése után a költséges ügyintézést követően nyolc-tizenkét hónapos várakozási idő után ítélik meg a magyarországi nyugdíj folyósítását, miután Ukrajnában lemond minden tulajdonáról és az állampolgárságáról is. Ezzel együtt az ukrajnai nyugdíjáról is kénytelen 


\section{KÖZELKÉP}

lemondani. Tehát több mint félévig az igénylőnek semmilyen nyugdíja nincs, és ha pozitívan értékelik kérelmét, akkor egy összegben visszamenőleg a kérelem napjáig megkapja a számára megítélt összeget. De előfordul olyan eset is, hogy visszautasítják az igénylést, és így nyugdíj nélkül maradhat az illető. A visszautasítást követően az illetékes fellebbezhet, de ezzel még több járulékos költséggel jár az igénylés. A gyakori kudarcok illetve a végleges költözés félelme miatt egyre kevesebben döntenek a magyarországi nyugdíj megszerzése mellett. Az igénylés költségei miatt csak egy bizonyos réteg számára válik elérhetővé ez a kettős állampolgárságból származó előny.

A beszélgetések vezérfonalába iktattuk be azt a kérdést, mely az etnicitást és a nacionalizmust hivatott előhívni. A kérdés lényegében arra kérdezett rá, hogy a résztvevők közül bárki tapasztalt-e olyat, hogy ismerőseik közül a változó ukrán politikai illetve gazdasági helyzetben átalakult a viszonya a magyar etnikumhoz, és esetleg a korábbi szélsőséges ukrán nacionalizmust felváltotta a magyar szimpátia. A következő, valamint a többi esetekben is arra hivatkoznak a résztvevők, hogy leginkább a nyelvhasználaton keresztül válik leginkább érzékelhetővé a változás - a korábban (csak) ukránul tudók egyre többen kezdtek el magyar nyelven tanulni. Tehát a következő válaszban a nyelvhasználaton keresztül vált érzékelhetővé az a nézőpontváltás, amelyben az addig tapasztalt magyar etnikumtól szélsőséges elzárkózást a nyugdíj megszerzésének folyamatában felváltotta a magyar szimpátia. Egy gazdaságilag előnyösebb lehetőség igénylése alakította az illető etnikai kategóriákban gondolkodását, és az addig csak negatív következményekkel járó etnikumtól elzárkózás átváltott a kategóriához társított pozitív előny következtében. A diskurzusban arra utalt az egyik adatközlő, hogy főként az ilyen hirtelen váltást az értelmiségi rétegen belül tapasztalta leginkább, amely helyi szinten gyakran az egészségügyben dolgozókat (orvosokat, ápolókat), pedagógusokat vagy egyéb fontosabb hivatali posztot betöltő személyeket jelent.

Magdolna (női fodrász, nyugdíjas 61 éves): „Volt olyan, olyan az intelligenciából ugye, aki meg se akart szólalni, egy szót se+... Nem mondok neveket. Hát bizony, most már ugye Magyarországra jár hetente: a nyugdíj rendezése, ez az, úgyhogy."

Moderátor: „Az értelmiségi réteg? Azt tetszett mondani?”

Magdolna: „Igen, igen.”

Moderátor: „Aha. Tehát főként azokban a körökben volt.”

Magdolna: „Igen, akkor nem akart meg se szólalni magyarul.”

Enikő (tanár, 34 éves): „Egy ilyen például nekem is van egy ö hölgy elmúlt hatvan éves, és ö nagyon-nagyon régóta, hát már vagy húsz éve biztos, hogy ismerem. Én is, a család is. Számunkra furcsa volt, mert+... Soha egy szót sem beszélt magyarul, de tényleg, egy szót sem, csak ukránul. Még úgy is tett, mint aki nem érti. Most ugye a politikai változásoknak köszönhetően, ugye elmúlt hatvan, jól jönne a magyarországi nyugdíj, kiderült az ő édesapja magyar, de hogy olyan szinten, hogy ők otthon 


\section{KÖZELKÉP}

az apjával magyarul beszélgettek. Csak ugye nem Beregszászban született, és meszsziről jött ember bármit mondhat+... Annyira nem messze, de Beregszászi járásnak az egyik falujába, és, és az ő édesapja teljesen magyar volt, és ők otthon magyarul beszélgettek, és ezt egy x éven át senki nem tudta. Ez már csak akkor derült ki ugye, mikor lehetőség akadt arra, hogy, hogy magyar állampolgárságot szerezhessen. Ez azért úgy+... Igen, és ilyenre nagyon sok példa van." (FCS6)

A rétegbeli különbségek mutatkoznak tehát az állampolgárság megszerzéséből adódó előnyök kihasználása kapcsán. A külföldi munkavállalás mindenkinek adott, de a nyugdíj megszerzése már réteg specifikus. Az idősebb korosztályban az előnyösebb nyugdíj megszerzése az egykor, illetve még a mai napig az értelmiségi rétegbe tagozódók (szellemi foglalkozásúak) számára sokkal inkább elérhető, illetve a megítélt nyugdíj is pozitívabb ennek a rétegnek. A leginkább szembetűnő eset, amikor valaki pont a beosztása miatt - és a beosztásán keresztül létrejött kapcsolatrendszerén belül - volt „kénytelen” csak az államnyelven kommunikálni, majd ezt alakítva iktatja be kommunikációjába a jobb előnyökkel járó etnikum nyelvhasználatát, esetenként felelevenítve az addig elhallgatott származását. A kisebbségi etnikum esetén nyelvhasználattól való elzárkózás ténye egyet jelent az etnikumhoz tartozás tagadásával, vagy legalábbis az „alattomos” elhallgatásával. A nyelvhasználat tehát ebben az esetben is az etnikumhoz tartozás indikátora, és jelzi, hogy az adott illető részt kíván-e venni az etnikai kategóriába tartozás tényével, vagy sem. Az identitás képlékenységének igazolására tökéletes példájává válik egy olyan orvos, aki élete legnagyobb hányadában munkája során csak az ukrán (esetleg orosz) nyelvet használta, ám a jobb nyugdíj érdekében az addig csak ukrán nyelvhasználatát és ukrán etnikumhoz erős vonzalmát a magyar etnikumhoz ragaszkodás váltja fel. Ez a jelenség többes kötődésủ személyek számára, illetve azok számára, akik az államalkotó nemzet kapcsolathálójában kénytelen boldogulni ez természetes, ám azok számára, akik csak a „magyar világban” (Hires-László 2016, Brubaker és mts. 2011, Enyedi 1993, Kántor 2000, Brubaker 2001) élik mindennapjaikat kevésbé

A nyugdíj mellett a magyarországi jobb egészségügyi ellátás egy újabb olyan lehetőség, mely a kettős állampolgárságon keresztül a körkörös migrációt serkenti, majd a végleges kiköltözést eredményezheti. A lehetőség abban rejlik, hogy az adott illetőnek magyarországi bejelentett lakcímen túl az egészségügypénztárban igényelt TAJ-kártyának a költségeit havi rendszerességgel szükséges fedezni, amennyiben nem nyugdíjas, kiskorú vagy a magyarországi munkáltatója fedezi ennek költségeit. Az Ukrajnában uralkodó rossz gazdasági helyzet nemcsak az egészségügy ellátás infrastruktúráját tette tökre, hanem a jó szakképzettséggel és szakértelemmel rendelkező orvosok is külföldön vállalnak munkát, vagy végleg elhagyják az országot családjukkal együtt. Erről szól a következő idézet is, az adatközlő, aki felvetette a kérdéskört, érintett volt, és egy komolyabb mútét valamint kezelés következtében tapasztalta ennek a mechanizmusát, illetve az ellátásban tapasztalt különbségeket, 


\section{KÖZELKÉP}

előnyöket. Erre a pozitív élményre építve alakult ki a sokkal erősebb érzelmi kapcsolata a magyar állampolgársághoz és az egész államhoz.

Eszter (éjszakásnevelő, 42 éves): „Igen. Nem történt veled olyan dolog, mint velem, és én ott találtam meg a biztonságot, és mai napig is inkább oda húz a szívem, úgyhogy."

Moderátor: „Az egészségügy miatt nem?”

Eszter: „Jó, hogy nem olcsó, mert ugye a fél havi fizetésem, de akkor is, inkább oda fizetem, mert itt sajnos, hogy már innen az orvosok is kivándoroltak, kimentek, itt már nem találsz egy-egy+..." (FCS3)

Az előző idézet előzményeként hangzott el az lokális identitást hangsúlyozó vélemény, melyben résztvevő azt hangsúlyozta ki, hogy ő nem szeretné igényelni az állampolgárságot és semmilyen formában igénybe venni az ezekből eredő előnyöket. Az illető nem beregszászi lakos, hanem a környező településen él és oda is két éve házasodott egy körülbelül száz km távolságról, a szórvány térség egyik településéről.

Lilla (kollégiumi nevelő, 29 éves): „Hát én úgy vagyok ezzel az egész állampolgársággal, hogy én magyar vagyok, ö magyarok leszármazottja, én isten tudja meddig vissza tudom vezeti a családfámat, nálunk mindenki magyar, és magyarul gondolkodok, magyarul imádkozok, de én nem vagyok kettős állampolgár, sőt nem is szeretnék kettős állampolgár lenni. Nekem elveim vannak, én kárpátaljai vagyok, nem azt mondom, hogy Ukrajnában élek, hanem én kárpátaljai vagyok, és én itt szeretnék élni, azt szeretném, hogy a családom is itt maradjon. És én mindent megteszek azért, hogy mi itt is maradjunk, én nem szeretnék sehova elmenni, én itt érzem jól magam, itt születtem itt szeretnék meghalni, és Magyarországtól semmiféle támogatást nem kérek, se nyugdíjt, se fizetést semmi, én ha megyek, akkor csak rokonlátogatóba, és arra nekem bőven elég a vízumom, ami az ukrán útlevelembe van, én nem szeretnék kettős állampolgár lenni."

Erre a domináns kijelentésre érkezett tehát az a válasz, hogy az élethelyzetek sok mindent átrajzolhatnak, és a véleménye, az érzelmi kötődése is abba az irányba mozdulhat el, ahonnan nagyobb biztonságot kap a nehezebb helyzetekben. Az erős lokális érzetet és egyúttal az állampolgársághoz való viszonyt, tehát egy mindennapokban átélt élethelyzet markánsan átrajzolhat, és felválthatja egy másik helyhez, állampolgársághoz való ragaszkodás.

A vándorlás következményeiről egyszer sem kellett az adatközlőket kérdezni: automatikusan vetették fel a tendenciákat - az itthon maradás lehetőségét és kényszerét, valamint az elvándorlás okait és következményeit egyaránt megvitatták. Kárpátaljai boldogulással kapcsolatban két vélemény is megjelent az iskolázottság összefüggésében: egyesek szerint azok költöznek el, akik tanultak és jó végzettségükkel, szakértelmükkel itthon nem tudnak mit kezdeni, másrészt azok az egykori iskolatársak, akik az átalagon alul teljesítettek és az itthon maradáshoz nem volt elég „tudásuk”. Vagyis az elvándorlás mindenkit érint, függetlenül az iskolázottság- 


\section{KÖZELKÉP}

tól, vagy szakértelemtől. A leghangsúlyosabb a beszélgetésekben az iskolázottság és az elvándorlás összefüggésében az ukrán nyelvtudás - amennyiben valaki nem sajátítja el kellőképpen az államnyelvet, az jobban rákényszerül az elvándorlásra. De egyik adatközlő arra is hozott példát, hogy ukrán nemzetiségű ismerőse csak és kizárólag külföldön tervezi a jövőjét. Egy a napokban bemutatott Research \& Branding Group független kutatócsoport által 2017 júniusában végzett szociológiai kutatás adatai szerint Ukrajna lakosságának 33\%-a szeretné végleg elhagyni az országot ${ }^{5}$.

Anikó (kollégium igazgatója, 53 éves): „Mert Ukrajnába megélni nem lehet a mai napra, mindenki tudja te is tudod, te is, te is, hogy fizetésből, itt már csak azok maradnak, akik vagy nem tudnak elmenni, vagy vagy+/."

Lilla: „Nem teheti meg."

Anikó: „Vagy nem akar, mer olyan is van, aki nem akar.”

Zsófia (éjszakai nevelo, 39 éves): „Én nem akarok.”

Eszter: „Én se. [nevet] Hiába lehet, hogy ott jobban érvényesülne az ember.”

Anikó: „Szívük szerint senki nem akarna innént elmenni.”

Eszter: „Van olyan ismerősöm, aki kimondottan azért tanul, mert el akar menni, és ukrán."

Anikó: „Mert el akarnak menni."

Eszter: „Nem érdekli azt, hogy ő+... Ukrajnába ugye nem leli a helyét.”

Anikó: „Mert nem tud megélni.”

Eszter: „Igen.”

Anikó: „Miért akar, miért akar elmenni egy ember a szülőföldjéről, miért vágyik el, mert látja, hogy ő csak dolgozik, dolgozik, dolgozik, nincs semmije, nem halad sehová." (FCS3)

A legnagyobb erősítő tényező, mint ahogy az elemzés kezdetén is említettük, a jobb megélhetés, az Ukrajnában jellemző alacsony bérezés a nyugati országok bérezéséhez viszonyítva sokkal alacsonyabb. Ez a viszonyítási lehetőség korábban nem volt jelen a térségben - vagy ha igen, akkor kisebb hangsúllyal - de napjaikban már ebben a viszonylatban történik az összehasonlítás az egyre több mobilitás lehetőséget nyújtó lehetőségeken keresztül. Az interjúk készítésekor még csak a kettős (ukrán-magyar) állampolgárságon keresztül tudtak legegyszerűbben utazni illetve külföldön munkát vállalni, 2017 nyarára már az ukrán állampolgárok vízummentesen utazhatnak Európai Unió országaiba, illetve egyre több kedvezményt adnak a külföldi munkavállalás terén is azok számára, akik csak ukrán állampolgársággal és az új biometrikus útlevéllel rendelkeznek.

${ }^{5}$ http://rb.com.ua/rus/projects/omnibus/9184/ 


\section{KÖZELKÉP}

\section{5. Összefoglalás}

A migráció pont úgy, mint az etnicitás több szempontból is átitatja a kárpátaljai magyarok hétköznapjait. Az elvándorlást elsősorban a családegyesítés és a jobb megélhetés miatt választják elsősorban a kárpátaljai magyarok. Ezekre a motiváló tényezőkre az ukrajnai bizonytalan helyzet még fokozottabb hatással van, melyben egy újabb pluszt jelent a kettős állampolgárság megléte és igénybevétele. A migrációban fiatalabb generáció a leginkább érintett, de láthattunk egy-két ellenpéldát is, ahol épp a fiatalabb generáció gondolta úgy, hogy kötelessége a helyben maradás. A kárpátaljai magyarok helyben maradása érdekében a Magyar Kormány több támogatási politikát is kidolgozott (többek között a legfontosabbak az Egán Ede terv, Bethlen Gábor Alap pályázatai stb.), hogy pont a migráció legerősebb motivációját, a jobb megélhetés miatti elvágyódást semlegesítsék. Az idősebb generációt is érintő nyugdíj miatti kényszeres elköltözést serkentette viszont a magyarországi szigorítások. Megoldás lehetne, ha nemcsak az aktív korosztályúak, családosok számára (iskoláztatás, nagycsaládosok támogatása) dolgoznának ki támogatást, hanem a nyugdíjasokat is megcéloznák, és egy pályázati keretet különítenének el nyugdíjak kiegészítésére. A helyben maradás másik fontos tényezője az államnyelvtudás. Az ukrán nyelv elsajátítása még mindig megoldatlan kérdés, és a nyelvet iskolai keretek között szinte lehetetlen megtanulni megfelelő szinten. Az Ukrán Államnak úgy tűnik nem is célja, hogy a kisebbség másodnyelvként sajátítsa el azt. Az ukrán nyelv tanításának ésszerű, korszerű metódusának a kidolgozása volna célravezető, mivel ezzel a jövő nemzedék helyben maradásának a jövőbeli boldogulását oldhatnák meg. Az elvágyódás és helyben maradás a kárpátaljai magyarok életében mindennapos téma, a hétköznapi etnicitás vizsgálatában kimagaslóan magas szereppel bír pont úgy, ahogy a megélhetési problémák is.

\section{Irodalom}

Appadurai, Arjun (1996): Modernity at Large: Cultural Dimension of Glabalization. Minneapolis: University of minnesota Press.

Berger, Peter - Luckmann, Thomas (1991): The social construction of reality. London: Penguin Books.

Brubaker, Rogers - Cooper, Frederick (2000): Beyond „identity”. Theory and society 29, 1-47. Forrás: http://www.sscnet.ucla.edu/soc/faculty/brubaker/Publications/18_Beyond_Identity.pdf

Brubaker, Rogers - Feischmidt, Margit - Fox, Jon - Grancea, Liana (2011): Nacionalista politika és hétköznapi etnicitás egy erdélyi városban. Budapest: L’Harmattan.

Brubaker, Rogers (2001): Csoportok nélküli etnicitás. Beszélő 7., 60-66. 


\section{KÖZELKÉP}

Brubaker, Rogers (2006) Nacionalizmus új keretek között. Budapest: L'Harmattan.

Cojocaru, Stefan (2010): Appreciative supervision in social work. New opportunities for changing the social work practice. Revista de cercetare si interventie sociala, 2010, vol. 29, 72-91.

Csernicskó István - Soós Kálmán (2002): Mozaik 2001. Gyorsjelentés - Kárpátalja. In: Mozaik 2001. Magyar fiatalok a Kárpát-medencében, Budapest: Nemzeti Ifjúságkutató Intézet. 91-135.

Csernicskó István (2016): Nyelvpolitika a háborús Ukrajnában. Ungvár: Autdor-Shark, $140 \mathrm{p}$.

Enyedi Zsolt (1993): Pillér és szubkultúra. A politikai-kulturális tagolódás egy lehetséges fogalmi kerete. Politikatudományi Szemle, 4. 21-50.

Fedinec Csilla - Halász Iván - Tóth Mihály (2016): A független Ukrajna. Államépítés, alkotmányozás és elsüllyesztett kincsek. Budapest: MTA Társadalomtudományi Kutatóközpont, Kalligram, 232 p.

Feischmidt Margit (2010): Megismerés és elismerés: elméletek, módszerek, politikák az etnicitás kutatásban. In Feischmidt Margit szerk. Etnicitás. Különbségteremtő társadalom. Budapest: Gondolat-MTA Kisebbségkutató Intézet, 7-33. old.

Feishmidt Margit - Zakariás Ildikó (2010): Migráció és etnicitás. A mobilitás formái és politikái nemzeti és transznacionális térben. In Feischmidt Margit szerk. Etnicitás. Különbségteremtő társadalom. Budapest: Gondolat-MTA Kisebbségkutató Intézet,152-169. old.

Galbin, Alexandra (2014): An introduction to Social Constructionism. Social Research Reports, 2014, vol. 26, pp. 82-92.

Gereben Ferenc (2005): Olvasáskultúra és identitás. A Kárpát-medence magyarságának kulturális és nemzeti azonosságtudata. Budapest: Lucidus Kiadó.

Göncz Borbála - Lengyel György - Tóth Lilla (2012): Bevándorlók a magyar társadalom tükrében. Méltóság, igazságosság és civil integráció. Budapest: Budapesti Corvinus Egyetem, 280 p.

Hammersley, Martyn - Atkinson, Paul (2007): Ethnography: Principles in practice (third edition). London: Routletge.

Hires-László Kornélia (2010): „Az öreg fát nagyon nehéz kivágni”. A nemzeti és lokális identitás faktorai az ezredfordulón a kárpátaljai magyar közösségben. PoliPrint Könyvkiadó. Ungvár, 2010.

Hires-László Kornélia (2016): „Magyar világ” - magyar pillérek, oszlopok Beregszászon. In: Gazdag Vilmos - Karmacsi Zoltán - Tóth Enikő szerk. Értékek és kihívások II. Történelem- és társadalomtudományok, oktatásmódszertan, irodalomtudomány, 49-62. Ungvár: Autdor-Shark 
www. metszetek.unideb.hu

\section{KÖZELKÉP}

Hires-László Kornélia (2017): Etnikai kategóriák a beregszásziak mindennapi diskurzusaiban. In: Márku Anita - Tóth Enikő szerk. Többnyelvűség, regionalitás, nyelvoktatás. Tanulmányok a Hodinka Antal Nyelvészeti Kutatóközpont kutatásaiból III. Ungvár, „RIK-U”, 2017. 121-136.

Jorgensen, Marianne - Phillips, Louise J. (2002): Discourse Analysis as Theory and Method. London: SAGE Publications

Kántor Zoltán (2000): Kisebbségi nemzetépítés. A romániai magyarság mint nemzetépítõ kisebbség. Regio 2000/3. 219-241.

Orosz Ildikó - Molnár Eleonóra (2007): Kárpátalja (Ukrajna). In Papp Z. Attila - Veres Valér szerk. 2007: A Kárpát-medencei magyarok társadalmi helyzete és perspektívái. Gyorsjelentés. 185-243. Budapest: MTA Etnikai-Nemzeti Kisebbségkutató Intézet

Tátrai Patrik - Erőss Ágnes - Kovály Katalin (2016): Migráció és versengő nemzetpolitikák Kárpátalján az Euromajdan után. REGIO 24/3. 82-110.

Vicsek Lilla (2006): Fókuszcsoport. Budapest: Osiris Kiadó 